\title{
Okul Psikolojik Danışmanlarının Nöbet Görevine İlişkin Görüşlerinin İncelenmesi
}

\author{
Hilal Kazua, Emrullah Deniz ${ }^{\mathrm{b}, \mathrm{c}}$
}

\section{Özet}

$\mathrm{Bu}$ araştırmanın amacı, eğitimin çeşitli kademelerinde görev yapan okul psikolojik danışmanlarının okul nöbeti görevine ilişkin yaşadıkları sorunları analiz etmek ve ortaya çıkan sonuçlar temelinde öneriler sunmaktır. Araştırmada nitel araştırma desenlerinden olan fenomenoloji (olgubilim) deseni kullanılmıştır. Araştırma, 17 okulda görevli 22 psikolojik danışman ile yarı yapılandırılmış görüşme tekniği kullanılarak gerçekleştirilmiştir. Araştırmanın verileri içerik analizi yöntemi doğrultusunda kategoriler oluşturularak analiz edilmiştir. Araştırma sonuçlarına göre psikolojik danışmanların nöbet görevi nedeniyle çeşitli zorluklar yaşadıkları, bu zorlukların çoğunun mesleki ilke ve sorumluluklar, etik standartlar, okul nöbetinin gerektirdiği yasal sorumluluklar ve okul nöbeti sırasında yaşanan krize müdahale stratejileri ile ilgili olduğu görülmektedir. Araştırma, psikolojik danışmanların okul nöbeti hakkındaki düşünce, problem ve önerilerini ortaya koyması ve okul nöbeti ile ilgili yapılacak çalışmalara ışık tutması açısından önemli görülmektedir.
Anahtar Kelimeler

Okul Nöbeti

Okul Psikolojik Danışmanı

Rehber Öğretmen

Okul Güvenliği

Makale Hakkında

Geliş Tarihi: 16.01.2020

Kabul Tarihi: 12.10 .2020

Doi: 10.18026/cbayarsos.675885

\section{Investigation of School Counselors' Views on the Guard Duty at School}

\section{Abstract}

The aim of this study is to analyze the problems of the school counsellors about school guard duty who work at different graduals and to suggest offers according to the results. For the study phenomenology which is a kind of qualitative research method was applied. The study has been carried out with 22 psychological counsellors who are on duty at 17 different schools by using semi structured interview. According to the results of the study, it has been seen that psychological counsellors have different problems during their school guard duty and most of which are releated to their professions' principle and responsibilities, ethics, legal responbilities and coping strategies used in crisis intervention. The study seems to be important in terms of revealing school counsellors' thoughts, problems and advices about school guard duty and enlightening further studies about school guard duty.
Keywords

School Guard Duty

Psychological Counselor

School Counselor

School Security

About Article

Received: 16.01 .2020

Accepted: 12.10 .2020

Doi: 10.18026/cbayarsos.675885

a Doç. Dr., Fırat Üniversitesi, Eğitim Fakültesi/Elazığ, ORCID: 0000-0001-9380-331X

b Doktora Öğr., Fırat Üniversitesi, Eğitim Bilimleri Enstitüsü/Elazı̆̆, ORCID: 0000-0002-3763-2234

c İletişim Yazarı: emrullah_0047@hotmail.com 


\section{Giriş}

Birey ve toplumdan beklenen tüm gelişmelerin temelinde eğitimin, dolayısıyla okulun olduğu bilinen bir gerçektir. Bireylerin, toplumdaki ortak değerleri ve sosyal becerileri aile ortamında edinmesi her zaman için mümkün olmayabilir; fakat okul, bireylerin, toplumun benimsediği ortak değerlerin yanı sıra, sosyal ve bilişsel beceriler edinmesi, diğer insanlarla iletişim kurmayı öğrenmesi bakımından zengin bir ortam sağlamaktadır. Dolayısıyla okullar, öğrencilerin günlük yaşamlarının büyük bir bölümünü geçirdikleri ortamlardır. 2017-2018 eğitim-öğretim dönemi okul öncesi, ilköğretim ve ortaöğretim kurumlarını kapsayan örgün eğitim istatistiklerine göre, ülkemizde örgün eğitime 17 milyon 885 bin 248 öğrenci devam etmektedir (MEB, 2018). İstatistiksel verilere göre, Türkiye nüfusunun \%20'sinin çeşitli okul kademelerinde eğitim etkinliklerine katıldığı söylenebilir. Okullarda eğitim-öğretim etkinliklerinin yanı sıra, doğal afetler, kazalar, yangın, alkol ve uyuşturucu madde kullanımı, şiddet içerikli terör olayları, hırsızlık gibi bir dizi potansiyel tehditlere karşı savunmasız kalındığı durumlar da yaşanabilmektedir. Buna bağlı olarak, öğrenciler, aileler ve tüm okul personelleri için güvenli okul ortamı; öğrencilerin kişisel, toplumsal ve akademik ihtiyaçlarını karşılaması bakımından odaklanılması gereken bir konu olarak karşımıza çıkmaktadır (Çalık, Kurt ve Çalık, 2011, s.74).

Eğitim-öğretim etkinliklerinin etkili bir şekilde yürütülmesi için güvenli okul ortamları gereklidir; çünkü eğitim-öğretim faaliyetleri, öğrencilerin kendilerini güvende hissedebilecekleri ortamlarda geçekleşebilmektedir (Hernandez ve Seem, 2004). Aksi takdirde, okul iklimi, öğrenme ortamı ve öğrenci motivasyonu olumsuz yönde etkilenmekte ve buna bağlı olarak okul terki, akademik ve eğitimsel uyum becerilerinde gerilemeler yaşanabilmektedir (Memduhoğlu ve Taşdan, 2008). Güven'e (2002) göre güvenli okul, uygun ve verimli öğrenme fırsatlarının sağlandığı bir ortamdır. Memduhoğlu ve Taşdan'a (2008) göre ise güvenli okul, temelde öğrenciler olmak üzere öğretmen, veli, okul personeli, ziyaretçi gibi paydaşların, fiziksel, sosyal ve psikolojik olarak kendilerini "özgür" hissedebilecek bir ortamdır. Bu bağlamda, öğrenciler açısından fiziksel ve psikolojik olarak uygun okul ortamlarının oluşturulması; bütün paydaşların katılımını gerektirmekte ve okul yöneticilerine daha fazla sorumluluk yüklemektedir (Özer ve Dönmez, 2013). Bu sorumluluğun önemli bir paydaşı olan yöneticilerin; güvenli okul ortamı ve buna bağlı olarak güvenli okul ikliminin oluşmasında ve başarılı bir okul kimliğinin gelişmesinde önemli rollere sahip oldukları belirtilmektedir (Dönmez, 2001). Bir diğer önemli paydaş olan ve okul güvenliğinin sağlanmasına destek olan aile; öğrencilerin bir sosyal sistem olan okul ortamına uyum sağlaması, otorite ilişkilerini öğrenmesi, şiddet içerikli ve işlevsiz davranışlardan kaçınması bakımından önemli bir aktördür (National Education Association [NEA], 2005, s.5). Son olarak öğretmenler, eğitim-öğretim sürecinin gerektirdiği görevlerin yanı sıra, öğrenciler için risk taşıyan zaman dilimlerinde (öğle arası, teneffüs saatleri) öğrenci güvenliğini sağlamakla görevli önemli bir diğer unsurdur.

Ülkemizde öğrenci güvenliğinin sağlanması ve eğitim-öğretim faaliyetlerinin düzenli bir şekilde yürütülmesinde okul yönetimine yardımcı olmak amacıyla nöbetçi öğretmen uygulaması yapılmaktadır. Nöbetçi öğretmen uygulaması ile ilgili olarak MEB İlköğretim Kurumları Yönetmeliği'nde, “İlköğretim kurumlarında; okulun bina ve tesisleri ile öğrenci mevcudu, yatıl, gündüzlü, normal veya ikili eğitim yapma gibi durumları göz önünde bulundurularak okul müdürlüğ̈̈nce düzenlenen nöbet çizelgesine göre öğretmenler, normal eğitim 
yapan okullarda gün süresince, ikili öğretim yapan okullarda ise kendi devresinde nöbet tutarlar" denilmektedir (2014: md. 44). Adı geçen yönetmelikte, nöbet görevinin işleyişi ile ilgili olarak okul yöneticilerinin sorumlu olduğu, nöbet esaslarının özel durumlar hariç (sağlık sorunları, hamilelik vb.) bütün öğretmenleri kapsadığı ve yasal yükümlülükler içerdiği açık bir şekilde belirtilmektedir. Dolayısıyla, nöbetçi öğretmenler, okul binası ve bahçesinde yaşanabilecek kriz durumlarını yönetme, düzen ve disiplini sağlamakla görevlidirler (Ayyıldız ve Akın, 2016, s.350).

MEB'in ulusal düzeyde uyguladığı ve okullarda koruyucu, önleyici tedbirleri kapsayan ve öğrencilerin aitlik ve güven duygusunu artırıcı uygulamaları da içeren nöbetçi öğretmenlik uygulaması, okul yönetimi ve öğretmenlerin yanı sıra, 2017 yılında yayınlanan Rehberlik Hizmetleri Yönetmeliği ile okul psikolojik danışmanları tarafından da yerine getirilmektedir. Öğrenci kişilik hizmetlerinin merkezinde yer alan psikolojik danışmanlık; bireyin, kendini tüm yönleriyle gerçekçi olarak tanımasına, çevresinde var olan fırsatları keşfetmesine, problem çözebilme yeterlilikleri geliştirebilmesine, seçimler yapabilmesine, kendine ve çevresine uyum sağlama ve kendini gerçekleştirmesine yönelik hizmetler bütünlügüüür (International Association for Counselling [IAC], 2003; Topses, 2007, s.5; Bond, 2013). Okul psikolojik danışma hizmetlerinin yürütülmesinde bir çerçeve niteliği taşıyan ilkeler yer almaktadır. Bunlar genel olarak; danışanın koşulsuz olarak kabul edilmesi, bireye ve bireysel farklılıklara saygı duyulması, bilimsel ilkelerin dikkate alınması, hizmetlerin gizlilik esaslı ve gönüllüğe dayalı olarak yürütülmesi, gelişimsel bir anlayışla önleyici ve koruyucu yaklaşımın benimsenmesi, danışanın ihtiyaçlarına ve anlattıklarına odaklanılması ve çok kültürlülüğge duyarlılığın benimsenmesi olarak sıralanmaktadır (Hornbay, Hall ve Hall, 2003, s.4; Hackney ve Cormier, 2005; MEB, 2017). Belirtilen ilkeler doğrultusunda hizmetlerin sağlanabilmesi için, öğretmen ve velilerle işbirliği yapmanın yanı sıra, psikolojik danışmanlara önemli görevler düşmektedir. Psikolojik danışmanlardan beklenen görevler/roller, ülkemizde MEB Rehberlik Hizmetleri Yönetmeliği'nde (MEB, 2017) belirlenmiştir. İlgili yönetmelikte bu görevler/roller, özet olarak; (a) rehberlik hizmetleri programının hazırlanması, (b) sinıf rehberlik planlarının hazırlanması ve uygulanmasında sınıf rehber öğretmenlerine yardımcı olunması, (c) öğrencilerin eğitsel, mesleki ve kişisel/sosyal gelişimlerini sağlamak amacıyla bireysel rehberlik ve grup rehberliği hizmetlerinin yürütülmesi, (d) bireyi tanıma tekniklerinin uygulanması (e) bireysel veya grupla psikolojik danışma yapılması, (f) özel eğitim ihtiyacı olan öğrenciler ve velilerine yönelik eğitim hizmetlerinin yürütülmesinde kurumlarla işbirliği yapılması, (g) aile rehberliği hizmetlerinin yürütülmesi ve (h) rehberlik hizmetlerinin yürütülmesinde öğretmenlere, velilere ve bu hizmetlerin yürütülmesinde yer alabilecek diğer kişilere müşavirlik hizmetlerinin sağlanması şeklinde yer almaktadır. Diğer taraftan Amerikan Okul Psikolojik Danışmanlar Birliği'ne (ASCA, 2009) göre psikolojik danışmanların rolleri şu şekilde belirtilmektedir: Okullarda profesyonel bir yardım hizmeti sunan psikolojik danışmanlar, öğrencilerin ihtiyaçlarına dönük olarak ve gelişimsel bir program çerçevesinde; öğrencilerin akademik, kişisel-sosyal ve mesleki gelişimlerinde aktif olmalıdır. Danışmanların bir diğer görevi de okul psikolojik danısma programını geliştirmesi ve öğrencilerin bireysel gelişim planlarının hazırlanması sürecinde önleyici, iyileştirici ve krize müdahale edici içeriklere sahip hizmetler sunmalarıdır. Bu süreçte okul yönetimi ve diğer paydaşlarla (öğretmenler, aileler, resmi kurumlar vb.) işbirliği yapılmalıdır. Son olarak, psikolojik danışmanlardan, uygulanan psikolojik danışma programının etkililiğinin incelenmesi, okul temelli psikolojik danışma hizmetlerinin yürütülmesi sürecinde yaşanan 
aksaklıkların belirlenmesi ve elde edilen verilerin analizini içeren sonuç raporlarının oluşturulması beklenmektedir. Okul psikolojik danışma ve rehberlik (PDR) hizmetlerinin yürütülmesinde genel olarak psikolojik danışmanlardan yukarıdaki görevleri/rolleri bütüncül olarak organize etmeleri ve bu süreçte aktif rol oynamaları beklenmektedir.

Çağdaş eğitim yaklaşımları öğrencilerin çok yönlü gelişimini amaçlamaktadır. Bu yaklaşımlara göre öğrencinin, çok çeşitli ihtiyaçlarının olduğu ve bu ihtiyaçların çok çeşitli hizmet alanlarıyla karşılanması gerektiği vurgulanmaktadır. Bu hizmet alanlarının tümü öğrenci kişilik hizmetleri olarak tanımlanır. Bu çerçeve içinde yer alan okul temelli gelişimsel psikolojik danışma hizmetleri, eğitim-öğretim sürecinin vazgeçilmez bir parçasıdır (Hackney ve Cormier, 2005; Topses, 2007, s.24-26; Karaca ve İkiz, 2010, s.150-152;). Psikolojik yardım hizmetlerinin sunulmasında danışmanlar, Bond'un (2013) beş ulusal kuruluşa (British Association for Counselling and Psychotherapy [BACP], 2007; United Kingdom Council for Psychotherapy [UKCP], 2005; Counselling Psychology Division of the British Psychological Society [BPS], 2005; Confederation of Scottish Counselling Agencies [COSCA], 2008; Irish Association for Counselling and Psychotherapy [IACP], 1998) dayandırdığ çerçevesinde hareket etmelidirler. Bunlar; danışan güvenliği, mesleki yeterlilik ve uygulama için uygunluk, danışanların farklı yaşam tarzlarına ve inançlarına saygı, danışanın özerkliğine saygı, danışanların istismar edilmesi ile ilgili yasaklar, sözleşme, gizlilik ve uzmanlığın itibarını sürdürme görevi olarak sıralanmaktadır. Okul psikolojik danışmanları yukarıda değinildiği gibi, profesyonel bir rol üstlenerek, gelişimsel modele dayalı ve etik standartlar doğrultusunda psikolojik yardım hizmetlerini sunarlar. Diğer taraftan psikolojik danışmanların okul ortamında eğitimci rollerinin de bulunduğu (Paisley vd., 2006), danışman ve eğitimci olarak görev yapması gerektiği (Mcmahon, Mason ve Paisley, 2009) belirtilmektedir. Hornbay, Hall ve Hall (2003, s.33-34), psikolojik danışmanlar tarafından sınıfta, koridorda ve bir dersin sonunda yaşanan disiplin durumlarında; ilişkileri geliştirmek ve pekiştirmek için danışmanlık becerilerinin kullanılabileceğini belirtmektedirler. Ancak, bu hizmetler sunulurken çeşitli güçlükler yaşanmaktadır. Bu konuda daha önce yapılmış araştırmalar incelendiğinde (Hatunoğlu ve Hatunoğlu, 2006; Güneri, Büyükgöze-Kavas, 2007; Owen ve Owen, 2008; Dost ve Keklik, 2012); psikolojik danışmanların, salon ve koridorları gözetim altında tuttuğu, sınavlarda gözetmenlik yaptığı, boş geçen derslere girdiği, okul yönetimi ve diğer öğretmenlerle işbirliği yapamadığ1 ve psikolojik danışma hizmetlerine ilişkin olumsuz tutum ile baş etmek zorunda kaldığı saptanmıştır. Bunun yanı sıra MEB Rehberlik Hizmetleri Yönetmeliği'nde (2017) psikolojik danışmanlar için okul nöbeti grevinin zorunlu kılınması; psikolojik danışma hizmetlerinde yaşanan problemlerin artmasına, danışmanların otoriter ve kuralcı olarak algılanmasına ve danışman-öğrenci ilişkisinin olumsuz yönde etkilenmesine neden olabilmektedir.

Yukarıdaki açıklamalar doğrultusunda psikolojik danışmanların okul güvenliğini sağlamak amacıyla yerine getirdiği nöbet görevinin, psikolojik danışma hizmetlerini nasıl etkilediği ve bu süreçte yaşanılan zorlukların neler olduğu araştırılması gereken bir problem olarak düşünülmüştür. Bununla birlikte, yürürlükte olan MEB Rehberlik Hizmetleri Yönetmeliği'ne (MEB, 2017) göre uygulanması zorunlu olan okul nöbeti görevinin psikolojik danışmanlara ve PDR uygulamalarına yansımalarını içeren araştırma boşluğunun bulunması, ilgili literatüre katkı sunması açısından bu araştırmanın önemini ve gerekliliğini ortaya koymaktadır. Bu noktada psikolojik danışmanların nöbet sırasında neler hissettikleri, yaşadığı güçlükler ve çözüm önerilerinin güncel olarak ortaya koyulmasının yaşanılan 
problemlerin önlenmesine yönelik katkı sunacağı öngörülmektedir. Bu bilgiler 1şığında bu araştırmanın temel amacı; psikolojik danışmanların okul nöbeti görevi ile ilgili görüşlerinin belirlenmesidir. Bu temel amaç doğrultusunda aşağıdaki sorulara cevap aranmıştır:

a. Psikolojik danışmanlar okul nöbeti görevi ile ilgili neler hissetmektedirler?

b. Psikolojik danışmanların okul nöbeti görevi ile ilgili yaşadıkları zorluklar nelerdir?

c. Psikolojik danışmanlar tarafından okul nöbeti görevi sırasında yaşanılan zorluklarla baş etmek için neler yapılmaktadır?

d. Psikolojik danışmanların, okul nöbeti görevinin olumlu yönlerine ilişkin görüşleri nelerdir?

e. Psikolojik danışmanların, okul nöbeti görevinin daha etkili olabilmesine yönelik önerileri nelerdir?

\section{Yöntem}

$\mathrm{Bu}$ araştırma, nitel araştırma desenlerinden olan fenomenoloji deseninde gerçekleştirilmiştir. Fenomenoloji deseni, farkında olduğumuz ancak derinlemesine ve ayrıntılı bir anlayışa sahip olmadığımız olgulara odaklanmaktadır. Fenomenler yaşadığımız dünyada olaylar, deneyimler, algılar, yönelimler, kavramlar ve durumlar gibi çeşitli biçimlerde karşımıza çıkabilmektedir (Yıldırım ve Şimşek, 2013, s.72). Bu araştırmada da, psikolojik danışmanların okul nöbeti ile ilgili görüşleri incelenmeye çalışıldığ Fenomenoloji araştırmalarında veri analizi yaşantıları ve anlamları ortaya çıkarmaya yöneliktir. Dolayısıyla, bu araştırmada, katılımcıların okul nöbeti deneyimlerinin olması, fenomenoloji deseninin kullanılmasını gerekli kılmıştır. Fenomenoloji deseninde sonuçlar, betimsel bir anlatım ile sunulur ve sik sık doğrudan alıntılara yer verilir. Bunun yanında ortaya çıkan temalar ve örüntüler çerçevesinde elde edilen bulgular açıklanır ve yorumlanır (Yıldırım ve Şimşek, 2013, s.75). Bu araştırmada ele alınan olgu, okul nöbeti görevine yönelik psikolojik danışmanların uygulamaları, algıları ve yönelimleridir. Patton (2002), farklı bireylerin görüşlerinin detaylı bir şekilde incelenmesiyle araştırılan olgunun ayrıntılı bir şekilde açıklanabileceğini ifade etmiştir. Bu doğrultuda, yapılan bu araştırmada da, araştırılan olgunun ayrıntılı olarak sunulabilmesi için farklı okullarda görev yapan psikolojik danışmanların okul nöbeti ile ilgili görüşlerinin detaylı bir şekilde ele alınıp yorumlanmasına çalışılmıştır.

\section{Katılımcilar}

$\mathrm{Bu}$ araştırmanın katılımcıları, amaçlı rastgele örnekleme yöntemi doğrultusunda belirlenmiştir. Amaçlı rastgele örnekleme, araştırmanın amacı doğrultusunda durum örneklerinin sistematik ve tesadüfi olarak seçilmesi ve tasnif edilmesidir (Marshall ve Rossman, 2014; Akt., Baltacı, 2018, s.258). Bu doğrultuda 2018-2019 eğitim-öğretim yılında Mardin il merkezinde Milli Eğitim Bakanlığına bağlı okullarda görev yapmakta olan, aktif olarak nöbet görevini yerine getiren ve araştırmaya gönüllü olarak katılan 22 okul psikolojik danışman (rehber öğretmen) ile görüşülmüştür. Katılımcıların kişisel bulgularına ilişkin bazı istatistikler Tablo 1'de verilmiştir. 
Tablo 1. Katılımcılara İlişkin Bazı Bilgiler

\begin{tabular}{|c|c|c|c|c|c|}
\hline Cinsiyet & $\mathbf{N}$ & $\%$ & Yaş & $\mathbf{N}$ & $\%$ \\
\hline Kadın & 9 & 41 & $20-30$ & 11 & 50.0 \\
\hline Erkek & 13 & 59 & $30-40$ & 11 & 50.0 \\
\hline Kidem & \multicolumn{5}{|c|}{ Öğrenim } \\
\hline $1-5$ & 4 & 18 & Lisans & 16 & 73 \\
\hline 6-10 & 14 & 64 & Lisansüstü & 6 & 27 \\
\hline $11-15$ & 3 & 14 & & & \\
\hline $16-20$ & 1 & 4 & & & \\
\hline Çalışılan & \multicolumn{5}{|c|}{ Psikolojik Danışmanların } \\
\hline Kurum Türü & \multicolumn{3}{|c|}{ Kurumlara Göre Dağılımları } & $\mathbf{N}$ & $\%$ \\
\hline İlkokul & \multicolumn{3}{|c|}{ Rİ4, Rİ5, Rİ6, Rİ12, Rİ14, Rİ16 } & 5 & 23 \\
\hline Ortaokul & \multicolumn{3}{|c|}{$\begin{array}{l}\text { RO1, RO9, RO10, RO11, RO13, RO14, } \\
\text { RO19, RO20, RO22 }\end{array}$} & 9 & 41 \\
\hline Ortaöğretim & \multicolumn{3}{|c|}{$\begin{array}{l}\text { RL2, RL3, RL7, RL8, RL15, RL17, RL18, } \\
\text { RL21 }\end{array}$} & 8 & 36 \\
\hline Toplam & 22 & 100. & & 22 & 100.0 \\
\hline
\end{tabular}

Tablo 1'de görüldüğü gibi, araştırmaya 9'u (\%41) kadın, 13’ü (\%59) erkek olmak üzere toplam 22 psikolojik danışman katılmıştır. Katılımcıların yaş aralıklarının eşit orana (\%50) sahip olduğu görülmektedir. Kıdem dağılımına bakıldığında, 14 katılımcının 6-10 yıl aralığında kıdeme sahip olup, tüm katılımcıların \%64'ünü oluşturduğu görülmektedir. Katılımcıların \%73'ünün lisans düzeyinde öğrenim düzeyine sahip olduğu görülmektedir. Çalışılan kurum türüne bakıldığında, 9 katılımcının (\%41) ortaokul, 8 katılımcının (\%36) ise ortaöğretim kurumlarında çalıştı̆̆ 1 ve tüm katılımcıların \%77'sini temsil ettiği; 5 katılımcının (\%23) ise ilkokul kurumlarında çalıştığı anlaşılmaktadır.

\section{Veri Toplama Araçları}

$\mathrm{Bu}$ araştırmanın verilerinin toplanmasında, nitel araştırma yöntemlerinden görüşme tekniği kullanılmıştır. Görüşme tekniği, sözlü iletişim kanalıyla veri toplama tekniği olmakla birlikte; bireylerin bilgi, düşünce, tutum ve davranışları hakkında derinlemesine bilgi edinmeyi sağlar (Karasar, 2005). Görüşme tekniğiyle araştırmacı, aynı konuda farklı kişilerden benzer bilgilere ulaşabilmektedir (Yıldırım ve Şimşek, 2013). Araştırmada veriler, araştırmacılar tarafından geliştirilen "Yarı Yapılandırılmış Görüşme Formu" ile toplanmıştır. Görüşme formunun geliştirilmesi sürecinde psikolojik danışmanların nöbet görevine ilişkin görüş ve önerilerinin belirlenmesi amacı temel alınmıştır. Görüşme formu, araştırmacılar tarafından oluşturulduktan sonra, eğitim programları ve öğretim bilim dalında 1, psikolojik danışma ve rehberlik bilim dalında 1 olmak üzere toplam 2 alan uzmanının görüşleri doğrultusunda bazı değişiklikler yapılarak hazır hale getirilmiştir. Görüşme formu iki bölümden oluşmaktadır. Birinci bölümde katılımcıların cinsiyet, yaş, kıdem, eğitim düzeyi ve çalıştığı kurum türü gibi kişisel bilgilerini belirlemeye yönelik sorular; ikinci bölümde ise psikolojik danışmanları nöbet görevine ilişkin görüşlerini belirlemeye yönelik açık uçlu sorular yer almaktadır. Görüşme formundaki açık uçlu sorular, literatür taraması yapılarak hazırlanmıştır. Görüşme formunda yer alan sorular aşağıda sunulmuştur: 
a. Okullarda psikolojik danışmanlar (rehber öğretmenler) için uygulanması zorunlu olan okul nöbeti görevinin varlığı sizi nasıl etkiliyor? Lütfen açıklayınız.

b. Okul nöbeti görevi ile ilgili çoğunlukla karşılaştığınız zorluklar nelerdir? Lütfen açıklayınız.

c. Okul nöbetindeki zorlukları aşmak için neler yapmaktasınız, ne tür desteklere ihtiyaç duyuyorsunuz? Lütfen açıklayınız.

d. Okul nöbeti görevinin okul PDR hizmetlerine katkı sağladığını düşünüyor musunuz? Lütfen açıklayınız.

e. Okul nöbeti görevinin PDR ilklerine uygun olarak yürütülebilmesi ne gibi düzenlemelere ihtiyaç vardır? Lütfen açılayınız.

f. Yukarıdaki soruların dişında konuya ilişkin eklemek istediğiniz başka görüşleriniz varsa lütfen aşağıya yazınız.

\section{Verilerin Toplanması}

Araştırmanın verileri, 2018-2019 eğitim-öğretim yılının ocak-şubat aylarında Mardin İl Milli Eğitim Müdürlüğü'nden alınan izin sonrasında gerçekleştirilmiştir. Verilerin toplanması sürecinde, araştırmacılar tarafından ilgili okullar ziyaret edilerek psikolojik danışmanlara araştırmanın amaçları, süresi, prosedürü ve verilerin gizliliği hakkında bilgi verilmiştir. Ayrıca, araştırmaya katılımın gönüllülük esasına dayalı olduğu belirtilmiştir. Araştırmacılar tarafından ulaşılan 22 psikolojik danışmandan, okul nöbeti görevine ilişkin görüşlerini görüşme formundaki açık uçlu sorular doğrultusunda yazmaları istenmiştir. Araştırmanın tüm aşamalarında etik ilkelere dikkat edilmiştir.

\section{Verilerin Analizi}

Araştırmadan elde edilen veriler sistematik ve açı bir şekilde kodlanarak; birbirine benzeyen temalar ve kavramlar "İçerik Analizi" yöntemiyle analiz edilmiştir. İçerik analizinde amaç, araştırma kapsamında ulaşılan verileri açılayıcı kavram ve ilişkilere ulaşmaktır (Yıldırım ve Şimşek, 2013). Bu doğrultuda birbirine benzeyen veriler belli kavram ve temalar çerçevesinde toplanarak analiz edilir. Nitel araştırmalarda yaygın olarak kullanılan tematik gruplandırma ile araştırmacı, benzer ya da farklı içeriklere göre kategorilere ayrılan birimleri içsel bir tutarlılığı yansıtacak şekilde belirli kümeler altında bir araya getirip, ne anlam ifade ettiklerini bulmaya çalışır (Patton, 1990, s.384; Akt., Maxwell ve Barbara, 2008, s.466-467; Yıldırım ve Şimşek, 2013, s.260). İçerik analizinin gerektirdiği işlem basamakları takip edilerek; (a) verilerin kodlanması, (b) temaların/kategorilerin belirlenmesi, (c) kodların belirlenen temalar altında birleştirilmesi, (d) bulguların tanımlanarak yorumlanması işlemleri gerçekleştirilmiştir. Araştırmada aynı zamanda betimsel analiz de kullanılmıştır. Betimsel analizde, görüşülen ya da gözlenen bireylerin görüşlerini çarpıcı bir biçimde yansıtmak amacıyla doğrudan alıntılara yer verilir (Yıldırım ve Şimşek, 2013). Bu araştırmada da psikolojik danışmanların görüşlerinden doğrudan alıntılara yer verilmiştir. Katılımcların görüşme sürecine içtenlikle katılımlarını sağlamak amacıyla, araştırmacılar tarafından isimleri kodlanarak saklı tutulmuştur. Katılımcıların görüşlerinden alıntılar yapılırken izlenen yol şu şekildedir: Örneğin Rİ4 kodlamasında; R, psikolojik danışmanı; İ, ilkokul kademesini; 4 sayısı, dördüncü sırada görüşme yapılan psikolojik danışmanı temsil etmektedir. Benzer şekilde, RO1 ve RL2 gibi kodlamalarda “ $O$ " ve " $L$ ”, sirasiyla ortaokul ve lise kademelerini yansıtmaktadır. 
Yukarıda belirtilen aşamalar çerçevesinde, kodlama sürecinde oluşabilecek hataları engellemek amacıyla, 2 araştırmacı tarafından yapılan kodlama işlemi sonucunda kodlama güvenirliği (Güvenirlik=Örtüşenlerin Sayısı/ [Örtüşenler + Örtüşmeyenler Sayısı]) formülü kullanılarak güvenirlik düzeyi \%84 olarak hesaplanmıştır. Miles ve Hubermann (1994) tarafından, kodlama güvenirliğinin yeterlik düzeyinin \%80 ve üstü değerleri içermesi gerektiği belirtilmektedir (Akt., Baltacı, 2017, s.8). Güvenirliği artırmaya yönelik doğrudan alıntılara ekleme yapmadan yer verilmiş; araştırma sürecinde, bulguların kaydında ve analizinde açıklık benimsenmiş; araştırma sürecinin her adımı ayrıntılı olarak yöntem kısmında açılanmıştır.

\section{Bulgular}

\section{Okul Nöbeti Görevinin Psikolojik Danışmanları Etkileme Durumu}

Araştırmanın katılımcılarını oluşturan psikolojik danışmanların okullarda psikolojik danışmanlar için uygulanması zorunlu olan okul nöbeti görevinin kendilerini nasıl etkilediği ile ilgili görüşleri Tablo 2' de sunulmuştur.

Tablo 2. Psikolojik danışmanların okul nöbeti görevinin kendilerini nasıl etkilediğine ilişkin görüşleri

\begin{tabular}{|c|c|c|c|}
\hline Görüşler & Psikolojik Danışmanlar & $\mathbf{f}$ & $\%$ \\
\hline Uyum sağlamada zorlanıyorum & RO1, Rİ6, Rİ12, RL21, RO22 & 5 & 22.72 \\
\hline Rehberlik hizmetleriyle uyuşmuyor & RL2, RL3, RL15, Rİ16, RO20, RO22, & 6 & 27.27 \\
\hline Beni olumsuz etkiliyor & $\begin{array}{l}\text { RO1, RL2, RL3, Rİ4, RL7, RL8, RO11, RO13, } \\
\text { Rİ16, RL17, RL18, RO19, RO20, RO22 }\end{array}$ & 14 & 63.63 \\
\hline Rol karmaşası yaşıyorum & $\begin{array}{l}\text { RL3, RO10, RO13, Rİ16, RO19, RO20, RL21, } \\
\text { RO22 }\end{array}$ & 8 & 36.36 \\
\hline $\begin{array}{l}\text { Nöbet alanında yüksek sesle bağırmak } \\
\text { zorunda kalıyorum }\end{array}$ & $\begin{array}{l}\text { RO1, RL3, Rİ4, RL7, RO9, RO11, Rİ12, RL17, } \\
\text { RO19, RO20 }\end{array}$ & 10 & 45.45 \\
\hline Güven ilişkisini olumsuz etkiliyor & $\begin{array}{l}\text { RL2, RL3, Rİ4, RL7, RO9, Rİ16, RL17, RL18, } \\
\text { RO19, RL21, RO22 }\end{array}$ & 11 & 50.00 \\
\hline $\begin{array}{l}\text { Nöbet sırasında öfkemi kontrol etmede } \\
\text { zorlanıyorum }\end{array}$ & Rİ4, RO19, RL21 & 3 & 13.63 \\
\hline Çok yoruluyorum & RL15, RL17 & 2 & 9.09 \\
\hline Sorumluluklarım artiyor & RI5, RL15, RO22 & 3 & 13.63 \\
\hline
\end{tabular}

Tablo 2'de psikolojik danışmanların nöbet uygulamasına ilişkin çeşitli görüşleri yer almaktadır. Tablo incelendiğinde, psikolojik danısmanların yarısından fazlasının (\%63.63) nöbet uygulamasından dolayı olumsuz etkilendikleri görülmektedir. Bununla birlikte, nöbet uygulamasının öğrencilerle kurulan güven ilişkisini olumsuz etkilediği (\%50.00) ve danışmanların nöbet alanında yüksek sesle bağırmak zorunda kaldıkları (\%45.45) görülmektedir. Ayrıca, nöbet uygulaması nedeniyle danışmanların rol karmaşası yaşadığ 1 (\%36.36) ve nöbet görevinin rehberlik hizmetleri ile uyuşmaması (\%27.27) nedeniyle uyum sağlamada (\%22.72) güçlük çektiği anlaşılmaktadır. Psikolojik danışmanların görevli oldukları eğitim kademeleri bakımından öne çıkan görüşleri değerlendirildiğinde; ortaöğretim kademesinde görevli danışmanların eşit oranla \%75'i nöbet uygulamasının kendilerini olumsuz etkilediği ve danışanla kurulan güven ilişkisinin zarar gördüğü 
görüşündedirler. Ortaokul kademesinde görevli psikolojik danışmanların \%66.66'sı nöbet uygulamasından olumsuz yönde etkilendiğini belirtirken; eşit oranla \%55.55'i ise, rol karmaşası yaşadıklarını ve nöbet sırasında yüksek sesle bağırmak zorunda kaldıklarını belirtmişlerdir. İlkokul kademesinde görevli psikolojik danışmanlar ise, \%60 oranla nöbet uygulamasından rahatsızlığını dile getirmiştir. Bu boyutta yer alan katılımcıların örnek görüşleri aşağıda sunulmuştur:

"Daha önce var olmayan bu yeni uygulamaya adapte olmak beni olumsuz anlamda etkiledi." (RO1)

"Nöbet uygulaması, rehberlik hizmetleriyle taban tabana zıt durumda. Nöbet uygulaması, rehberlik hizmetlerini büyük oranda sekteye uğrattığından, biz rehber öğretmenleri de olumsuz anlamda etkilemektedir." (RL2)

“Öğrencilere yüksek sesle müdahale etmek zorunda kalıyorum.” (RO11)

“Nöbet gününde öğrencilerle görüşmede sorunlar yaşanıyor. Nöbet görevinde öğrencilere kızdığımızdan dolayı rehberlik sürecine karşı tavır almalar oluyor." (RO10)

“Öğrenci görüşmelerinin çoğu teneffüste gerçekleştiği için nöbet esnasında öğrencileri geri göndermek durumunda kalıyoruz. Nöbet esnasında öğrencilere bă̆ırmak, öğrencilerin bize bakış açılarını değgiştirmekte. Bizi otoriter bir figür olarak görmesine neden olduğunu düşünmekteyim."(RO13)

\section{Okul Nöbeti İle İlgili Çoğunlukla Karşılaşılan Zorluklar}

Okul psikolojik danışmanlarının okul nöbeti ile ilgili sıklıkla karşılaştıkları sorunlara ilişkin görüşleri Tablo 3'te sunulmuştur.

Tablo 3. Psikolojik danışmanların okul nöbeti görevi ile ilgili yaşadıkları zorluklara ilişkin görüşleri

\begin{tabular}{llcc}
\hline Görüşler & Psikolojik Danışmanlar & f & \% \\
\hline $\begin{array}{l}\text { Krize müdahale hizmetleri gecikiyor } \\
\text { ya da yapılamıor }\end{array}$ & RO1, RO9, RO14, RL15, RO20, RO22 & 6 & 27.27 \\
\hline Görüşmeler aksıyor, erteleniyor & $\begin{array}{l}\text { RO1, RL2, Rİ6, RO13, RO14, RL15, Rİ16, RL21, } \\
\text { RO22 }\end{array}$ & 9 & 40.90 \\
\hline Herhangi bir zorluk yaşamıyorum & RL2, RL17, RL18 & 3 & 13,63 \\
\hline Rehberlik hizmetleri aksıyor & $\begin{array}{l}\text { RL2, RL3, RI4, Rİ5, Rİ6, RL7, RO9, RO10, RO11, } \\
\text { Rİ12, RO13, RO14, RL15, RO19, RO20, RL21, } \\
\text { RO22 }\end{array}$ & 17 & 77.27 \\
\hline $\begin{array}{l}\text { Hizmetlerin yanlış tanımlanmasına } \\
\text { neden oluyor }\end{array}$ & $\begin{array}{l}\text { RO1, RL3, Rİ4, Rİ6, RO10, RO13, RL15, Rİ16, } \\
\text { RO19, RO20, RL21, RO22 }\end{array}$ & 12 & 54.54 \\
\hline $\begin{array}{l}\text { Nöbet görevi nedeniyle okul idaresi } \\
\text { ile tartışma yaş1yorum }\end{array}$ & Rİ16, RO22 & 2 & 9.09 \\
\hline $\begin{array}{l}\text { Nöbet görevi nedeniyle rehberlik } \\
\text { servisine yapılan başvurular azalıyor }\end{array}$ & RO1, RL3, Rİ4, Rİ16, RO20, RO22 & 6 & 27.27 \\
\hline $\begin{array}{l}\text { Nöbet görevi, görüme sürecinin } \\
\text { bölünmesine neden oluyor }\end{array}$ & $\begin{array}{l}\text { Rİ4, Rİ5, Rİ6, RL7, RL8, RO9, RO10, RO11, } \\
\text { Rİ12, RO13, RL15, RL18, RL21, RO22 }\end{array}$ & 14 & 63.63 \\
\hline $\begin{array}{l}\text { İdari personel olarak alg1lanmamiza } \\
\text { neden oluyor }\end{array}$ & RL3, RO22 & 2 & 9,09 \\
\hline
\end{tabular}


Tablo 3'te psikolojik danışmanların nöbet görevi sırasında yaşadıkları zorluklara ilişkin görüşleri yer almaktadır. Tablo bulgularından, danışmanların büyük bir bölümünün $(f=17$; \%77.27) nöbet görevi nedeniyle rehberlik hizmetlerinin aksadığı görüşünde olduğu görülmektedir. Bunu sırayla; nöbet görevi nedeniyle görüşmelerin bölündüğü $(f=14$; \%63.63), hizmetlerin yanlış tanımlanmasına neden olduğu ( $f=12 ; \% 54.54)$, görüşmelerin aksadığı $(f=9 ; \% 40.90)$, krize müdahale hizmetlerinin geciktiği $(f=6 ; \% 27.27)$, rehberlik servisine yapılan başvuruların azaldığ $1(f=6 ; \% 27.27)$, okul idaresi ile tartışmaların yaşandığ $(f=2 ; \% 9.09)$ ve psikolojik danışmanların idari personel olarak algılanmasına $(f=2 ; \% 9.09)$ neden olduğu yönünde problemler takip etmektedir. Ayrıca, psikolojik danışmanların 3'ü (\%13.63) herhangi bir zorluk yaşamadığını belirtmiştir. Psikolojik danışmanların görevli oldukları eğitim kademeleri bakımından nöbet görevi ile ilgili öne çıkan görüşleri değerlendirildiğinde; ilkokul kademesinde eşit oranla hizmetlerin aksadığ $(f=4 ; \% 80)$ ve görüşme sürecinin bölünmesine neden olduğu $(f=4 ; \% 80)$; ortaokul kademesinde rehberlik hizmetlerini aksattığ $(f=8 ; \% 88.88)$; ortä̈ğretim kademesinde ise, yine eşit oranla $(f=5 ; \% 62.5)$ hizmetlerin aksadığı ve görüşme sürecinin bölünmesine neden olduğu tespit edilmiştir. Bu boyutta yer alan katılımcıların örnek görüşleri aşağıda sunulmuştur:

“...Mesela nöbetçi olduğum gün hastalanan bir öğrenciye eşlik etmek için hastaneye gönderildiğim zamanlar oldu. Planladı̆̆ım çalışmaları ve görüşmeleri ertelemek zorunda kaldım. Ayrıca öğrencilerim o anlarda bana ulaşamadı..." (RL15)

“Veli ya da öğrenci ile görüşme bitmemişken nöbet görevine gitme durumunda kahyorum." (Rं́)

“Öğrencilerin istenmeyen davranışlar sergilemesi, okul yönetiminin ara stra nöbetle ilgili kızgın davranmaları, görüşmelerin bölünmesi ve yoğunluğun artması. Nöbet görevinin olduğu gün, rehberlik hizmetleri yapılamaz hale gelmektedir. O günün tamamı nöbet gündemiyle geçmektedir. Rol karmaşası yaratmaktadır." (RO22)

"Daha çok teneffüslerde bize ulaşmaya çalışan öğrencilerimiz, gelip bizi görmüyorlar ya da nöbet esnasında gelip söyledikleri zaman erteliyoruz. Bu da öğrencilere anında müdahale şansımızı azaltıyor." (RO9)

"Disiplin olayları genellikle nöbet sırasında gerçekleşebiliyor. Olaya müdahale ederken disiplin alanında bulunuyoruz. Bu da öğrencilerin bize bakış açısını olumsuz etkiliyor." (RO19)

\section{Okul Nöbeti İle İlgili Karşılaşılan Zorluklarla Baş Etmek Amacıyla Tercih Edilen Yollar ve İhtiyaç Duyulan Destek Kaynakları}

Psikolojik danışmanların okul nöbeti sırasında karşılaştıkları zorluklarla baş etme yolları ve bu süreçte ihtiyaç duydukları destek kaynakları ile ilgili görüşlerini yansıtan cevapların dağılımı Tablo 4'te sunulmuştur. 
Tablo 4. Psikolojik danışmanların okul nöbeti sırasında yaşanan zorlukları aşmak için neler yaptıkları, ne tür desteklere ihtiyaç duyduklarına ilişkin görüşleri

\begin{tabular}{llcc}
\hline Görüşler & Psikolojik Danışmanlar & f & $\%$ \\
\hline $\begin{array}{l}\text { Kriz durumlarında nöbet görevimi başka bir } \\
\text { ögretmene devrediyorum }\end{array}$ & RO1, RL8, Rİ14, Rİ16, RL21 & 5 & 22.72 \\
\hline Problem durumları görmezden geliyorum & RL3 & 1 & 4.54 \\
\hline $\begin{array}{l}\text { Kriz durumlarında okul idaresinden destek } \\
\text { alıyorum }\end{array}$ & $\begin{array}{l}\text { RL2, Rİ, Rİ5, RO10, RL15, RL17, } \\
\text { RL21 }\end{array}$ & 7 & 31.81 \\
\hline $\begin{array}{l}\text { Önleyici rehberlik kapsamında, nöbet sırasında } \\
\text { görüşme yapıyorum }\end{array}$ & Rİ5, RO13, RL17 & 3 & 13.63 \\
\hline $\begin{array}{l}\text { Herhangi bir çözüm yolu olduğunu } \\
\text { düşünmüyorum }\end{array}$ & RL7, RL8 & 2 & 9.09 \\
\hline $\begin{array}{l}\text { Rehberlik servisinin bulunduğu katta nöbet } \\
\text { görevini yerine getirerek kontrolü sağllyorum }\end{array}$ & RO9, RL21 & 2 & 9.09 \\
\hline Kriz durumunda görev alanını terk ediyorum & RO9, RO13, RO22 & 3 & 13.63 \\
\hline $\begin{array}{l}\text { Nöbetim sirasında sınıf başkanlarından destek } \\
\text { alıyorum }\end{array}$ & RO10 & 1 & 4.54 \\
\hline $\begin{array}{l}\text { Herhangi bir desteğe ihtiyaç duymuyorum } \\
\text { Problem durumlarında sadece gözlem yapıyorum }\end{array}$ & Rİ12 & 1 & 4.54 \\
\hline
\end{tabular}

Tablo 4'te psikolojik danışmanların nöbet görevine ilişkin zorluklarla baş etmek ve bu süreçte ihtiyaç duydukları destek hizmetlere ilişkin çeşitli görüşleri yer almaktadır. Tablo incelendiğinde, psikolojik danışmanların 7'si (\%31.81) kriz durumlarında okul yönetiminden destek aldığını belirtmiştir. Öne çıkan bir diğer çözüm yolunun ise, kriz durumlarında nöbet görevinin başka bir öğretmene devredilmesi $(f=5 ; 22.72)$ şeklinde olduğu görülmektedir. Danışmanların okul kademelerine göre öne çıan görüşleri incelendiğinde; kriz durumlarında okul idaresinden destek alınmasının, ilkokul $(f=2 ; \% 40)$ ve ortaöğretim $(f=4 ; \% 50)$ kademelerinde; kriz durumlarında nöbet bölgesinin terk edilmesinin ise ortaokul $(f=3$; \%33.33) kademesinde görevli danışmanlar tarafından daha çok tercih edildiği görülmektedir. Bu boyutta yer alan katılımcıların örnek görüşleri aşağıda sunulmuştur:

"Ders içi ve ders dışı etkinliklerde bu durumu okul öğrencileri ve idare ile görüşüp var olan sorunlarm üstesinden geliyorum." (Rİ5)

"Okul idaresi bu anlamda önemli. Onlarla uzlaşmaya çalışıyorum. Nöbeti, odamın bulunduğu katta tutmak istediğimi belirttim. Zaman zaman diğer nöbetçi öğretmenlerin desteğine ihtiyaç duyuyorum." (RL21)

"İdareden destek almaya çalışıyorum. İdaremle iletişim halindeyiz. Nöbetle ilgili bir sıkıntı yaşadığımda ya da nöbet yerine gidemediğimde, idareye neden nöbet yerimde olmadığıma dair bilgi veriyorum." (RL15)

“...Görüşmem gereken öğrencileri odamda bekletip sonra görüşüyorum ya da acil durum ise nöbeti bırakıp öğrenci ile ilgileniyorum." (RO9)

"Kriz durumlarında rehberlik hizmetlerine öncelik tanıyorum. Nöbet alanına gidemediğim çok zaman oluyor. Örneğin, veli görüşmesi sürerken nöbet görevine gidemiyorum. Bu da yasal olarak birtakım sakıncaları barındırıyor." (RO22) 


\section{Okul Nöbeti Görevinin PDR Hizmetlerine Katkıları}

Araştırmada bir diğer belirlenmek istenen durum, okul nöbeti görevinin psikolojik danışma ve rehberlik hizmetlerine (PDR) ne gibi yararları olabileceğine yönelik katılımcıların görüşleridir. Bu duruma ilişkin bulgular Tablo 5'te sunulmuştur.

Tablo 5. Okul nöbeti görevinin PDR hizmetlerine sunduğu yararlara ilişkin görüşler

\begin{tabular}{llcc}
\hline Görüşler & Psikolojik Danışmanlar & f & \% \\
\hline \multirow{2}{*}{$\begin{array}{l}\text { PDR hizmetlerine herhangi bir katkı sağladığını } \\
\text { düşünmüyorum }\end{array}$} & $\begin{array}{l}\text { RO1, RL2, RL3, Rİ4, Rİ, RL7, } \\
\text { RL8, RO9, RO11, Rİ12, RO13, }\end{array}$ & & \\
& $\begin{array}{l}\text { RO14, RL15, Rİ16, RL18, RO19, } \\
\text { RO20, RL21, RO22 }\end{array}$ & 86.36 \\
\hline PDR hizmetlerine katkı sağladığını düşünüyorum & RO10, Rİ12, RL17 & 3 & 13.63 \\
\hline Gözlem yapma fırsatı sağlıyor & Rİ4, Rİ5, RO10, RL17 & 4 & 18.18 \\
\hline $\begin{array}{l}\text { Diğer öğretmenlerle empati kurulması açısından fayda } \\
\text { sağlıyor }\end{array}$ & RL17 & 1 & 4.54 \\
\hline $\begin{array}{l}\text { Sınıf ve okul etkinliklerine katılmayan psikolojik } \\
\text { danışmanlar için yararlı olduğunu düşünüyorum }\end{array}$ & RL17 & 1 & 4.54 \\
\hline
\end{tabular}

Tablo 5'te danışmanların nöbet görevinin PDR hizmetlerine sunduğu katkılara ilişkin görüşleri yer almaktadır. Tablo verilerine göre; danışmanların büyük bir bölümü $(f=19$; \%86.36) nöbet uygulamasının PDR hizmetlerine herhangi bir katkı sağlamadığ1 görüşündedir. Diğer taraftan, nöbet görevinin gözlem yapma fırsatı sunduğu $(f=4 ; \% 18.18)$ görüşünü savunanlara da rastlanmıştır. Okul kademelerine göre danışmanların görüşleri değerlendirildiğinde; bütün kademelerde (ilkokul, ortaokul ve ortaöğretim) nöbet görevinin PDR hizmetlerine katkı sunmadığı görüşünün ön plana çıktığ görülmektedir. Bu boyutta yer alan katılımcıların örnek görüşleri aşağıda sunulmuştur:

"Ortaokulda çalıştığım süre içerisinde herhangi bir katkı görmedim; aksine öğrencilere sık sık yasaklar, kurallar ve yaptırımları hatırlatarak onları rehberlik servisinden uzaklaştırdığııı gözlemledim. Nöbet tuttuktan sonra öğrencilerim benim için 'hoca aslında sinirliymiş' dediklerini duydum." (Rİ4)

"Kesinlikle hayır." (Rİ16)

"Katkı sağlamıyor. Tam tersine mesleğimize zarar verdiği kanısındayım." (RO19)

“Kesinlikle katkı sağlamıyor. Aksine rehberlik hizmetleri ile hiç de uyuşmuyor. Öğrenci ile kurduğumuz bütün iyi ilişkileri bozuyor. Kurulmamış olan iyi ilişkilerin kurulmasını engelliyor. Öğrenci, rehber öğretmenini okuldaki diğer öğretmenlerden farklı görmüyor. Hatta idarenin bir personeli olarak görmeye başlıyorlar. Çünkü nöbetçi öğretmen olarak tutanak tutulup, öğrenciye ceza verilmesi de söz konusu olabiliyor." (RL3)

"Katkı să̆ladığın düşünmüyorum. Bugüne kadar tuttŭ̆um nöbet görevlerinin okulda yürüttü̈̆̈̈mmüz PDR hizmetlerini bulunduğu noktadan daha üst bir noktaya taşıdığına dair herhangi bir faydası olduğunu gözlemlemedim ve okulumuzdaki öğrenci, öğretmen, velilerden ve idareden nöbetin rehberlik faaliyetlerine bir faydası olduğuna dair geri bildirim almadım." (RL15) 


\section{Okul Nöbeti Görevinin PDR İlkelerine Uygun Olarak Yürütülebilmesi İçin Yapılması Gerekenler}

Araştırmada psikolojik danışmanlara okul nöbeti görevinin PDR ilkelerine uygun olarak yürütülebilmesi için neler yapılması gerektiği sorulmuştur. Verilen cevaplar Tablo $6^{\prime}$ da yer almaktadir.

Tablo 6. Okul nöbeti görevinin PDR ilkelerine uygun olarak yürütülebilmesi için ihtiyaç duyulan düzenlemelere ilişkin görüşler

\begin{tabular}{llcc}
\hline Görüşler & Psikolojik Danışmanlar & f & \% \\
\hline Nöbet görevinin gönüllülük esaslı olması gerekir & $\begin{array}{l}\text { RO1, Rİ5, RL7, Ri்12, RO13, } \\
\text { RL17, RO19, RL21, RO22 }\end{array}$ & 9 & 40.90 \\
\hline Okul idaresinin esnek davranması gerekir & RO1, RL18, RO22 & 3 & 13.63 \\
\hline Nöbet görevi ile ilgili düzenlemeler yapılmalıdır & RO1, RO22 & 2 & 9.09 \\
\hline $\begin{array}{l}\text { Psikolojik danısmanlar nöbet görevinden muaf } \\
\text { olmalıdır }\end{array}$ & $\begin{array}{l}\text { RL2, Rİ4, Rİ6, RL8, RO11, } \\
\text { RO14, Rİ16, RO20, RL21 }\end{array}$ & 9 & 40.90 \\
\hline Nöbet görevi gözlem yapma amacıyla yapılmalıdır & RL3, RO22 & 2 & 9.09 \\
\hline $\begin{array}{l}\text { Nöbet komisyonu kurularak, problemlere çözüm } \\
\text { üretilmelidir }\end{array}$ & RO22 & 1 & 4.54 \\
\hline $\begin{array}{l}\text { PDR ilkelerine uygun olarak yürütülebileceğini } \\
\text { düşünmüyorum }\end{array}$ & RO10, RO11, RL15, Rİ16, \\
\hline Nöbet görevi kolay yönetilebilir alanlarda yapılmalıdır & RL3, RO9, RL17 & 5 & 22.72 \\
\hline
\end{tabular}

Tablo 6'da görüldüğü üzere, nöbet görevinin PDR ilkelerine uygun olarak yürütülebilmesine yönelik ihtiyaç duyulan düzenlemelere ilişkin görüşlerin, eşit oranla $(f=9 ; \% 40.90)$ nöbet görevinin gönüllülük esaslı olması ve danışmanların nöbet görevinden muaf olması gerektiğine yoğunlaştı̆̆ı gözlenmiştir. Okul kademelerine göre danışmanların görüşleri değerlendirildiğinde ise; ilkokul ve ortaöğretim kademelerinde nöbet görevinin isteğe bağlı olması ve psikolojik danışmanların nöbet uygulamasından muaf olması gerektiği görüşlerinin benzer olduğu, ortaokul kademesinde ise nöbet uygulamasının isteğe bağlı olması gerektiği görüşünün ön planda olduğu görülmektedir. Bu boyutta yer alan katılımcıların örnek görüşleri aşağıda sunulmuştur:

“Gönüllü öğretmenler nöbet tutmalıdır." (RO1)

"Nöbet isteğe bağhl olmalıdır." (Rİ5)

“Nöbet görevi gönüllü̈̆ge dayalı olarak yapılmalıdır. Nöbet görevi esasları daha net olarak belirlenmeli ve esneklik sağlanmalıdır. Ayrıca, nöbet görevi sırasında karşılaşılan güçlüklerin aşılması için, okullarda 'nöbet komisyonu' gibi bir uygulama yapılmalıdır. Bu komisyonda danışmanlar da bulunmalı ve nöbet günlükleri paylaşılıp çözümler üretilmelidir." (RO22)

"Rehber öğretmen ve psikolojik danışman nöbet tutmamalıdır." (Rİ)

"Nöbet görevinin kaldırılmasının daha iyi olacağını düşünüyorum." (RO14)

"Nöbet görevinin kaldırılması daha olumlu olacaktır. Fakat bu yapılmayacaksa bile en azından isteğe bağlı bir şekilde sürdürülmelidir." (RL21) 


\section{Tartışma, Sonuç ve Öneriler}

Okullarda etkili ve verimli eğitim-öğretim faaliyetlerinin gerçekleştirilmesi için okulların tüm paydaşlar için güvenli bir yer olması gerekmektedir. Güvenli okul, bütün öğrencilerin öğrenme hedeflerini önemseyen, başarıya odaklanan, öğrencilerin güven ortamında sosyal beceriler edinmelerini sağlayan, öfke kontrolünü pekiştiren, yaşanan sorunlara ortak paydada çözümler üreten ortamlardır (Çelik, 2004). Okul güvenliğinin sağlanmasında önemli bir unsur olan psikolojik danışmanlar için, genel eğitim öğretmenlerine yönelik uygulanması zorunlu olan okul nöbeti görevi; MEB Rehberlik Hizmetleri Yönetmeliği'nde (2017: md. 34) yapılan yeni düzenleme ile zorunlu kılınmıştır. Bu bağlamda, bu araştırmada okul psikolojik danışmanlarının okul nöbeti görevi ile ilgili düşünceleri, yaşadıkları zorluklar ve nöbet uygulamasına ilişkin önerilerinin içerik analizi yoluyla incelenmesi amaçlanmıştır. Danışmanların görüşleri incelendiğinde bunların çeşitli kategoriler altında toplanabildiği ve betimlenebildiği görülmüştür. Araştırma kapsamında elde edilen bulgulardan ön plana çıkan noktalar aşağıda sunulmuş ve bu noktalar ilgili literatür ışığında tartışılmıştır.

Araştırma kapsamına alınan ilkokul, ortaokul ve ortaöğretimde görevli psikolojik danışmanların zorunlu nöbet görevine ilişkin görüşlerini içeren sonuçlar birlikte değerlendirildiğinde; danışmanların büyük bir bölümünün bu uygulamadan dolayı olumsuz etkilendikleri, nöbet sırasında kontrolü sağlamada zorlandıkları ve buna bağlı olarak da öğrencilere müdahale etmek zorunda kaldıkları saptanmıştır. Ayrıca, nöbet uygulamasının psikolojik danışma ve rehberlik ilkeleriyle uyuşmadığ PDR hizmetlerine herhangi bir katkı sağlamadığı, danışan-danışman ilişkisine zarar verdiği ve bunun sonucunda rol karmaşası yaşandığı belirlenmiştir. Daha önce yapılan araştırmalarda da danışmanların kendi görevleri dışındaki görevlere zaman ayırdıkları (örn. okul istatistikleri, boş sinıflarda görev alma vb.) (Hatunoğlu ve Hatunoğlu, 2006), yönetsel çalışmalarda bulunabildikleri (Owen ve Owen, 2008) saptanmıştır. Psikolojik danışmanlığın işlevi ve danışmanların sorumlulukları ile ilgili yapılan araştırmalarda (Kepçeoğlu, 1999; Burnham ve Jackson, 2000; Saylan ve Gürkan, 2002; Güven, 2005; B1çak, 2006; Akın, 2007; Polat, 2007; Nazlı, 2007; Başaran, 2008; Yeşilyaprak, 2009), danışmanların sorumluluklarına yönelik algıların; yönetici, öğretmen ve öğrenci görüşlerine göre farklılık gösterdiği saptanmıştır. Örneğin, Bassey, Monday ve Edet (2010), öğrencilerin psikolojik danışma hizmetlerine yönelik algılarını belirlemeye yönelik yaptıkları çalışmada, öğrencilerin rehberlik hizmetlerine yönelik tutumlarının anlamlı derecede olumlu olduğu sonucuna ulaşmışlardır. Benzer şekilde, Hue (2001) tarafından gerçekleştirilen çalışmada, sınıf içi disiplin problemleri ile baş etmede öğretmen ve psikolojik danışman işbirliğinin süreci kolaylaştırdığı ve buna bağlı olarak da öğrenci ve öğretmenlerin psikolojik danışma hizmetlerine karşı olumlu tutum geliştirdikleri saptanmıştır. Ancak, psikolojik danışma hizmetlerine ilişkin olumsuz tutum ve PDR hizmet alanlarıyla ilgili olmayan beklentiler de mevcuttur. Kepçeoğlu'nun (1999) ifade ettiği gibi, psikolojik danışmanlardan nöbet tutma, gözcülük yapma ve yönetim işlerine yardım etme gibi psikolojik danışmanlığın işlevine uygun olmayan görev ve sorumluluklar beklenmektedir. PDR hizmetlerinin en önemli unsuru olan psikolojik danışmanlar; mesleğin sınırları ile ilgili sorunlar, uzmanlık rol kimliğinin net olmaması gibi güncelliğini koruyan ve tartışılan birçok beklentiler (Lambie ve Williamson, 2004; Bardhoshi ve Duncan, 2009) nedeniyle, psikolojik yardım hizmetlerinin dışında kalan hizmetlerden sorumlu olabilmekte ve bunun sonucunda otorite sembolü, 
yönetsel işlerden sorumlu kişi olarak algılanabilmektedirler. ASCA'ya (2009) göre, kapsamlı gelişimsel psikolojik danışma ve rehberlik yaklaşımı, yönetimsel ve psikolojik danışma dışı görevleri benimsemez. Bunun yerine, öğrencilerin okulda ve yaşamda başarılı olmalarını sağlayan belirli yaşam becerileri ve deneyimlerini önemser (Cobia ve Henderson, 2007; Akt., Terzi, Tekinalp ve Leuwerke, 2009). Psikolojik danışmanla danışan arasında kurulan ilk ilişkinin önemine değinen Cormier ve Hackney (2007), bu sürecin, deneyimlerinden ve diğer bireylerden uzaklaşan danışanlara bütünlüğünü yeniden kazanma firsatları sunduğunu belirtmektedirler. Öğrencilerin kişisel/sosyal, mesleki ve akademik becerileri doğrultusunda birçok alanda hizmet sunan danışmanlar tarafından; okul PDR programının organize edilmesi, öğrenci gereksinimlerine uygun bireysel planlamalar yapılması, önleyici ve krize odaklı çalışmaların planlanması, okul personellerine yönelik müşavirlik hizmeti sunulması (Paisley ve McMahon, 2001; ASCA, 2009) gibi hizmetlerin yürütülmesi PDR hizmetlerinin okullardaki önemi ve gerekliliğini ortaya koymaktadır. Ancak, MEB tarafından yayınlanan Rehberlik Hizmetleri Yönetmeliği'nde (2017) psikolojik danışmanlar için nöbet görevinin zorunlu hale getirilmesi; yukarıda değinildiği gibi etik standartlar ve kapsamlı gelişimsel rehberlik modelinin gerektirdiği danışman sorumlulukları ile MEB tarafından belirlenen danışman sorumluluklarının birbirinden farklı olduğunu ortaya koymaktadır. Cormier ve Hackney'e (2007) göre rehberlik hizmetleri ile okulun disiplin uygulamaları amaç, önlem ve işlevleri açısından birbirinden ayrı birimlerdir. Psikolojik danışma ve rehberlik hizmetleri eleştiri ve cezanın olmadığı psikolojik yardım etme süreçlerini içermektedir. Nöbet görevi ise, aksine, öğrencilere yönelik birtakım cezalar ve müdahaleler gerektirmektedir.

$\mathrm{Bu}$ araştırmada nöbet görevinin gerektirdiği sorumlulukların okul yönetimi ile danışmanlar arasında çatışmalara kaynaklık ettiği danışmanlar tarafından belirtilmiştir. Psikolojik danışma ve rehberlik hizmetlerinde anahtar bir rol oynayan danışmanların, okul yönetimi ile işbirliği geliştirmeleri, danışmanların kendilerini yetkin görmelerinde (Gündüz ve Çelikkaleli, 2009), okul ikliminin olumlu yönde gelişiminde (House ve Martin, 1998; Hernandez ve Seem, 2004), öğrencilerin akademik becerilerini destekleyici öğrenme ortamlarının oluşmasında (Clemens, Milsom ve Cashwell, 2009; College Board, 2009; Armstrong, MacDonald ve Stillo, 2010) etkili olduğu vurgulanmaktadır. Önceki kısımlarda vurgulandığı gibi, PDR hizmetlerinin gerektirdiği rol ve sorumluluklar okul paydaşları ile uyumu, yöneticilerle yakın işbirliğini ve öğrenci gelişimine sistematik olarak katkı sunmayı gerektirmektedir. $\mathrm{Bu}$ açıdan değerlendirildiğinde, MEB tarafından okul nöbetinin danışmanlar için zorunlu olarak uygulamaya konması, danışman sorumlulukları ile nöbet görevinin gerektirdiği yasal zorunluluklar arasında uyumsuzluk oluşturması bakımından beklenmeyen bir adım olarak değerlendirilebilir. Diğer taraftan nöbet görevi ile ilgili yapılan bazı araştırmalarda (Çelikten, 2004; Memduhoğlu ve Taşdan, 2008; Gömleksiz, Kilimci, Vural, Köroğlu ve Erdal, 2008; Gündoğdu, Saraçoğlu, Altın ve Üstündağ, 2015), genel eğitim öğretmenleri tarafından uygulanan okul nöbeti görevinin okul kontrolü ve güven ortamını sağladığ1 belirtilmektedir. Grene (2005) okul güvenliğini, sadece fiziki düzenleme ve kontrolün sağlanması olarak değil, aynı zamanda okul personelleri, öğrenciler, aileler ve öğretmenler arasında bir güven geliştirme süreci olarak tanımlamaktadır (Akt., Çankaya, 2009). Araştırma kapsamındaki psikolojik danışmanların bir kısmının nöbet görevini gözlem yapma fırsatı olarak değerlendirmesi, bir kısmının ise nöbet görevinin PDR hizmetlerine katkı sunduğunu belirtmesi bu görüşü destekler niteliktedir. 
Okul güvenliğini nöbetçi öğretmen olarak sağlayan öğretmenler, bu süreçte birtakım zorluklar yaşamaktadırlar. Yapılan bazı araştırma bulgularının (Nezihoğlu, 2010; Özmen ve Aküzüm, 2010; Çiftçi, Meydan, Koçyiğit ve Kayılı, 2011; Özgan ve Bozbayındır, 2011) genel eğitim öğretmenlerinin yaşadığ güçlüklerin fiziksel yorgunluk, derse zamanında girememe, krize müdahale etme becerilerinin olmaması ve okul yönetimi ile yaşanan çatışma durumları gibi konularda yoğunlaştığı görülmektedir. Bu çalışmada ulaşılan sonuçlara göre ise, psikolojik danışmanların yaşadığı ve ön plana çıkan sorunlar; öğrencilerle yapılan görüşmelerin bölünmesi/aksaması, rehberlik hizmetlerinin aksaması, rehberlik hizmetlerinin yanlış tanımlanmasına neden olması ve krize müdahale hizmetlerinin gecikmesi yönündedir. Araştırmada elde edilen bulgular ve yukarıda değinilen araştırma sonuçları birlikte değerlendirildiğinde, danışmanlar ile genel eğitim öğretmenlerinin nöbet görevinde karşılaştığı güçlüklerin farklılaştığı söylenebilir. Bu farklılıkların; PDR hizmetlerinin belirli zaman aralıkları ile sınırlı olmaması (örn. genel eğitim öğretmenlerinin 40 dakika boyunca dersliklerde bulunması gerekirken; psikolojik danışmanların ise, çalışma saati ve görev türünden bağımsız olarak krize müdahale etmesinin gerekmesi gibi. Yine, sınıf rehberlik çalışmaları kapsamında hedef kazanım ile ilgili gerçekleştirilen etkinlik sonrasında, psikolojik danışman tarafından teneffüs aralarında mesleki rehberlik amaçlı görüşmelerin yapılması örnek olarak verilebilir), PDR hizmetlerinin merkezinde birey (danışan) önceliklerinin olması ve yönetimsel hizmetlerin bulunmaması (örn. sinıf ortamında istenmeyen davranış sergileyen bir öğrenci öğretmeni tarafından yasal işlem yapılması amacıyla disiplin kuruluna sevk edilebilirken; öğrencinin kişisel sosyal rehberlik kapsamında psikolojik danışman ile görüşmesinin, disiplin ve yönetimsel uyarıcılardan bağımsız olarak gerçekleşmesi gibi), danışman-danışan ilişkisinin güven temeline dayanması (genel eğitim uygulamalarında öğretmen-öğrenci arasında gerçekleşen ve çoğunlukla yapılandırılmamış ilişkilere dayalı iletişim sürecinden farklı olarak, güven temelli, temel ilke ve etik standartlar doğrultusunda gerçekleşen danışman-danışan ilişkisi, PDR hizmetlerine ilişkin algıları önemli ölçüde etkilediğinden; görüşmenin nöbet görevi nedeniyle sıkça bölünmesi danışan-danışman ilişkisine zarar vermekte ve buna bağlı olarak danışan tarafından yapılan PDR hizmet başvuruları azalabilmektedir) gibi nedenlerden kaynaklı olduğu söylenebilir.

Okul temelli psikolojik danışma hizmetlerinin başarılı bir şekilde sunulması, temel önleme hizmetlerinin gereksinimlere ve koşullara göre uyarlanması ve danışanların olası risk faktörlerine karşı korunması ile mümkündür. Bunu etkili kılmak için genel olarak önerilere bakıldığında; önleme çalışmalarının erken yaşlarda yapılması, kişi ve çevre etkileşiminin dikkate alınması, müdahale programlarının hazırlanması, farklı gruplarla işbirliği içinde olunması, aile ve öğretmenlerle işbirliği yapılması, akran desteğinin alınması ve öğrencilere sosyal becerilerin kazandırılması gerektiği vurgulanmaktadır (Korkut, 2007, s.27). Bu araştırmada ulaşılan sonuçlara göre danışmanlar, nöbet sırasında karşılaştıkları problemlerin çözümünde öğretmenlerle işbirliği yaptıkları, okul idaresinden destek aldıkları, önleyici çalışmalar yaptıkları ve krize müdahale ettiklerini vurgulamışlardır. Ancak, danışmanlar tarafından nöbet görevinin gerçekleştiği teneffüs saatlerinde koruyucu ve önleyici faaliyetlerin yeterince yapılmadığı; Aysan'ın (2005) da ifade ettiği gibi daha çok kriz ortaya çıktığ1 anda, problem çözme yöntemlerinin güçlendirilmesine yönelik krize müdahale edildiği saptanmıştır (Akt., Otlu, 2011, s.4). Bununla birlikte, krize müdahale etmede danışmanların birbirinden farklı ve sistematik olmayan uygulamalar yapmaları; 
danışmanların rehberlik hizmetleri öncelikleri ile nöbet görevinin gerektirdikleri arasında karmaşa yaşadıklarını ortaya koymaktadır.

$\mathrm{Bu}$ araştırmanın önemli bulgularından biri de, danışmanların büyük çoğunluğunun nöbet görevinin zorunlu olmaktan çıkarılıp isteğe bağlı olarak yapılması, nöbet görevinin kolay yönetilebilir alanlarda uygulanması ve okul yönetiminin esnek davranması gerektiğini belirtmiş olmalarıdır. Bulgular kısmında belirtildiği gibi, sayıları az da olsa bir kısım psikolojik danışman tarafından nöbet görevinin diğer öğretmenlerle empati kurulması ve öğrencilere yönelik gözlem yapma fırsatı sunması açısından faydalı olduğu belirtilmiştir.

Araştırmada ulaşılan sonuçlar doğrultusunda, aşağıdaki önerilerde bulunulabilir:

a. Genel eğitim öğretmenleri için belirli standartlara ulaşan nöbet görevi, psikolojik danışma hizmetlerinin yoğunlaştığı teneffüs saatlerinde uygulanması nedeniyle danışmanlar için çeşitli zorluklar doğurmaktadır. Bu nedenle, rehberlik hizmetlerinin gerektirdiği hizmetler doğrultusunda ilgili yönetmelikte çeşitli düzenlemeler yapılarak; nöbet görevinin kapsamlı ve gelişimsel uygulamaları barındıran, işbirliğini destekleyen ve rehberlik hizmetleri için vazgeçilmez bir unsur olan "etik standartlar" çerçevesinde uygulanan bir görev olarak yeniden tanımlanmasının yararlı olacağ düşünülmektedir.

b. Zorunlu olarak uygulanan okul nöbeti görevinin danışmanlar tarafından isteğe bağlı olarak uygulanması için, MEB tarafından düzenleme yapılması faydalı olabilir.

c. Önleyici rehberlik faaliyetleri kapsamına nöbet görevinde yaşanan/yaşanabilecek problemler de eklenerek, danışmanların baş etme stratejilerinin geliştirilmesine yönelik çalışmalar yapılabilir.

d. Yürütülecek bir başka araştırma ile okul yöneticilerinin, öğretmenlerin, ailelerin ve öğrencilerin psikolojik danışmanlar için uygulanması zorunlu olan nöbet görevi ile ilgili görüşleri belirlenebilir.

e. Okul nöbeti ile ilgili farklı bölgelerde daha geniş katılımcılar üzerinde yeni araştırmalar yapılması, sonuçların karşılaştırılması açısından yararlı görülmektedir.

\section{Kaynakça}

Akın, B. (2007). Rehber öğretmenlerin görevlerine ilişkin öğretmenlerin beklentileri ve alglları (Yüksek lisans tezi, Yeditepe Üniversitesi, İstanbul).

Armstrong, S. A., MacDonald, J. H., ve Stillo, S. (2010). School counselors and principals: different perceptions of relationship, leadership and training. Journal of School Counseling, $8,1-27$.

ASCA (American School Counselor Association). (2009). School Counselor Competencies. www.schoolcounselor.org. Erişim Tarihi:10.02.2019.

Aşkım, H. ve Yavuz, H. (2006). Okullarda verilen rehberlik hizmetlerinin problem alanları. Kastamonu Ĕ̆itim Dergisi, 14 (1).

Ayyıldız, A. ve Akın, U. (2016). Okul güvenliğinin sağlanmasında nöbetçi öğretmen uygulamasına ilişkin öğretmen görüşleri. Turkish Studies - International Periodical for the Languages, Literature and History of Turkish or Turkic, 11(3), 345-370.

Baltac1, A. (2017). Nitel veri analizinde Miles-Huberman modeli. Ahi Evran Üniversitesi Sosyal Bilimler Enstitüsü Dergisi, 3 (1), 1-15. 
Baltacı, A. (2018). Nitel araştırmalarda örnekleme yöntemleri ve örnek hacmi sorunsalı üzerine kavramsal bir inceleme. Bitlis Eren Üniversitesi Sosyal Bilimler Enstitüsü Dergisi, 7 (1), 231-274.

Bardhoshi, G. ve Duncan, K. (2009). Rural school principals' perceptions of the school counselor's role. The Rural Educator, 30 (3), 16-24.

Burnham, J. J. ve Jackson, C. M. (2000). School counselor roles: Discrepancies between actual practice and existing models. Professional School Counseling, 4(1), 41-49.

Bassey, M., Monday, A. ve Edet, A. (2010). Attitude of secondary school students towards guidance and counselling services in cross river state. Edo Journal of Counselling, 3 (1), 8799.

Başaran, M. (2008). İlköğretim okullarındaki yönetici ve sinıf rehber öğretmenlerinin psikolojik danışma ve rehberlik faaliyetlerinden beklentileri (Yüksek lisans tezi, Yeditepe Üniversitesi, İstanbul).

Bıçak, A. (2006). Resmi ilköğretim okulu rehber öğretmenlerinin görevlerini gerçekleştirme düzeyine ilişkin bir çalışma (Yüksek lisans tezi, Akdeniz Üniversitesi, Antalya).

Bond, T. (2013). Standarts and Ethics for Counselling in Action. Yeşilyaprak,B. (Çev.). Ankara: Nobel Yayınları.

College Board Advocacy. (2009). Finding A Way: Practical Examples of How An Effective Principal-Counselor Relationship Can Lead to Success for All Students.

http://professionals.collegeboard.com/profdownload/finding-a- way.pdf. Erişim Tarihi: 05.02.2019.

Cormier, S. ve Hackney H. (2014). Counselling Strategies and Interventions. Doğan, S. (Çev.). Ankara: Pegem Yayınları.

Clemens, E. V., Milsom, A. ve Cashwell, C. S. (2009). Using leader-member exchange theory to examine principal-school counselor relationships, school counselors' roles, job satisfaction, and turnover intentions. Professional School Counseling, 13, 75-85.

Çalık, T., Kurt, T. ve Çalık, C. (2011). Güvenli okulun oluşturulmasında okul iklimi: Kavramsal bir çözümleme. Pegem Ĕ̆itim ve Öğretim Dergisi, 1(4), 73-84.

Çankaya, İ. H. (2009). Okul güvenliği üzerine teorik bir çözümleme. Dicleüniversitesi Sosyal Bilimler Enstitüsü Dergisi, 1(2), 97-103.

Çelikten, M. (2004). Bir okul müdürünün günlüğü. Fırat Üniversitesi Sosyal Bilimler Dergisi, 14 (1), 123-135.

Çelik, K. (2005). Eğitimde acil durum yönetimi modeli önerisi ve uygulanabilirliği araştırması (Doktora Tezi, Ankara Üniversitesi, Ankara).

Çiftçi, S., Meydan, A., Koçyiğit, S. ve Kayılı, G. (2011). Sınıf öğretmenlerinin birlikte çalışma durumlarına ilişkin okul yöneticileri görüşleri. Selçuk Üniversitesi Ahmet Keleşoğlu Eğitim Fakültesi Dergisi, (32), 211-224.

Dost, M.T. ve Keklik, İ. (2012). Alanda çalışanların gözünden psikolojik danışma ve rehberlik alanının sorunları. Mehmet Akif Ersoy Üniversitesi eğitim Fakültesi Dergisi, 12 (23), 389-407.

Dönmez, B. (2001). Okul güvenliği sorunu ve okul yöneticisinin rolü. Kuram ve Uygulamada Ĕ̆itim Yönetimi, 7(25), 63-74.

Gömleksiz, M., Kilimci, S., Vural, R. A., Koçoğlu, Ç. ve Erdal, E. (2008). Okul bahçeleri mercek altında: Şiddet ve çocuk hakları üzerine nitel bir çalışma. İlköğretim Online, 7(2), 273-287.

Günay, G. ve Özbilen, F.M. (2014). İlköğretim öğretmenlerinin okul nöbeti görevleri üzerine bir değerlendirme. Mersin Üniversitesi Ĕ̆itim Fakültesi Dergisi, 10 (3), 64-78. 
Gündüz, B. ve Çelikkaleli, Ö. (2009). Okul psikolojik danışmanlarında mesleki yetkinlik inancı. Mersin Üniversitesi Eğitim Fakültesi Dergisi, 5 (1), 119-133.

Gündoğdu, K., Saracaloğlu, A.S., Altın, M. ve Üstündağ, N. (2015). Okul nöbetlerinin öğretmen görüşleri doğrultusunda incelenmesi: Problemler ve öneriler. İlköğretim Online, $14(1), 276-294$.

Güven, M. (2005). İlköğretimde çocuğu olan velilerin çocuklarının okullarındaki psikolojik danışma ve rehberlik hizmetlerine ilişkin algı ve beklentileri. XIV. Ulusal Eğitim Bilimleri Kongresi. Denizli: Pamukkale Üniversitesi Eğitim Fakültesi.

Hernandez, T. ve Seem, S. (2004). A safe school climate: A systemic approach and the school counselor. Professional School Counseling, 7 (4), 256-262.

Hornby, G., Hall, C. ve Hall, E. (2003). Counselling pupils in schools: Skills and strategies for teachers. New York: Routledge Falmer.

House, R. M. ve Martin, P. J. (1998). Advocating for better futures for all students: A new vision for school counselors. Education, 119 (2), 284-291.

Hue, M.T. (2001). A study of the relationship between school guidance and dicipline in Hong Kong secondary schools (Doctoral dissertation, University of London, London).

IAC (International Association for Counselling). (2003). https://www.iac-irtac.org/, Erişim Tarihi: 10.01.2019.

Karasar, N. (2005). Bilimsel Araştırma Yöntemi. Ankara: Nobel Yayın Dağıtım.

Karaca, R. ve İkiz, E. (2010). Psikolojik Danışma ve Rehberlikte Çă̆daş Bir Anlayış: Yaşamla İç İçe, Yaşam Boyunca. Ankara: Nobel Yayınları.

Kepçeoğlu, M. (1999). Rehberlik ve psikolojik danışma. Ankara: Alkım.

Korkut, F. (2007). Okul Temelli Önleyici Rehberlik ve Psikolojik Danışma. Ankara: Anı Yayincilik.

Lambie, G. W., ve Williamson, L. L. (2004). The challenge to change from guidance counseling to school counseling: A historical proposition. Professional School Counseling, $8(2), 124-131$.

McMahon, H., Mason, E., ve Paisley, P. (2009). School counselor educators as educational leaders promoting systemic change. Professional School Counseling, 13(2), 116-124.

Maxwell, J.A. ve Barbara, A.M. (2008). Handbook of Emergent Methods, (Ed.: Hesse- Biber, S.N. ve Leavy, P.), Categorizing and Connecting Strategies in Qualitative Data Analysis. London: The Guilford Press.

MEB. (Millî Eğitim Bakanlığı). (2019). 2017-2018 Eğitim İstatistikleri: Örgün Eğitim, https://sgb.meb.gov.tr/meb iys dosyalar/2018 09/06123056 meb istatistikleri orgun egitim 2017 2018.pdf, Erişim Tarihi: 02.02.2019.

MEB. (2017). Rehberlik Hizmetleri Yönetmeliği, http://www.resmigazete.gov.tr/eskiler/2017/11/20171110-2.htm, Erişim Tarihi: 20.01.2019.

MEB. (2014). Illköğretim Kurumları Yönetmeliği, http://www.resmigazete.gov.tr/eskiler/2014/07/20140726-4.htm, Erişim Tarihi: 15.01.2019.

Memduhoğlu, H.B. ve Taşdan, M. (2008). Okul ve öğrenci güvenliği: Kavramsal bir çözümleme. Çukurova Üniversitesi Ĕ̆itim Fakültesi Dergisi 3(34), 69-83.

Nazlı, S. (2007). Psikolojik danışmanların değişen rollerini algılayışları. Balıkesir Üniversitesi Sosyal Bilimler Enstitüsü Dergisi, 10 (18), 1-17.

NEA. (National Educaton Association). (2005). Safe Schools Manual, https://www.montgomerycountymd.gov/OLO/Resources/Files/SeriousIncident Report/2. pdf,Erişim Tarihi: 03.02.2019. 
Nezihoğlu, G. Ö. ve Sabancı, A. (2010). İlköğretim okul yöneticilerinin görüşlerine göre öğrencilerin istenmeyen davranışları ve bu davranışlarla başa çıkma yöntemleri. Pamukkale Üniversitesi Ĕ̆itim Fakültesi Dergisi, 28, 41-53.

Otlu, M.B. (2011). Okul psikolojik danışmanlarının krize müdahalede kullandıkları başaçıkma stratejilerinin incelenmesi: İzmir il örneği (Doktora Tezi, Dokuz Eylül Üniversitesi, İzmir).

Özabacı, N., Sakarya, N. ve Doğan, M. (2008). Okul yöneticilerinin okuldaki psikolojik danışma ve rehberlik hizmetlerine ilişkin görüşlerinin değerlendirilmesi. Balıkesir Üniversitesi Sosyal Bilimler Enstitüsü Dergisi, 11 (19), 8-22.

Özgan, H. ve Bozbayındır, F. (2011). Okullarda adil olmayan uygulamalar ve etkileri. Dicle Üniversitesi Ziya Gökalp Eğitim Fakültesi Dergisi, 16, 66- 85.

Özer, N. ve Dönmez, B. (2013). Güvenlik kameraları ve okul güvenliği: Bir ölçek geliştirme çalışması. Turkish Studies-International Periodical for the Languages, Literature and History of Turkish or Turkic, 8(3), 437-448.

Özmen, F. ve Aküzüm, C. (2010). Okulların kültürel yapısı içinde çatışmalara bakış açısı ve çatışma çözümünde okul yöneticilerinin liderlik davranışları. Sosyal ve Beşeri Bilimler Dergisi, 2(2), 65-75.

Paisley, P. O. ve McMahon, G. (2001). School counseling for the 21st century: Challenges and opportunuties. Professional School Counseling, 5 (2), 106-115.

Paisley, P. O., Ziomek-Daigle, J., Getch, Y. Q., ve Bailey, D. F. (2006). Using state standards to develop professional school counselor identify as both counselors and E. Guidance $\mathcal{E}$ Counseling, 21(3), 143-151.

Patton, M. Q. (2002). Qualitative Research Evulation Methods. California: SAGE.

Polat, C. (2007). İlköğretim okulları sekizinci sını öğrencilerinin okul psikolojik danışma ve rehberlik servisinden yararlanma düzeylerinin belirlenmesi (Yüksek lisans tezi, Frrat Üniversitesi, Elazı $\breve{g})$.

Saylan, N. ve Gürkan, U. (2002). Rehberlik hizmetleri yönetmeliğine göre rehberlik hizmetlerinin değerlendirilmesi (Bildiri kitabında özet basılan bildiri). VII. Eğitim Bilimleri Kongresi, 9-11 Eylül 1998, Selçuk Üniversitesi, Konya.

Terzi, Ş., Tekinalp, B.E. ve Leuwerke, W. (2009). Psikolojik danışmanların okul psikolojik danışma hizmetleri modeline dayalı olarak geliştirilen kapsamlı psikolojik danışma ve rehberlik programını değerlendirmeleri. 10. Ulusal Psikolojik Danışma ve Rehberlik Kongresi, Adana.

Topses, G. (2007). Psikolojik Yardım Hizmetleri Kuram ve Uygulamalar: Rehberlik ve Psikolojik Danışma Önleyici Rehberlik. Ankara: Nobel Yayınları.

Yerin Güneri, O., Büyükgöze Kavas, A. ve Koydemir, S. (2007). Okul Psikolojik Danışmanlarının Profesyonel Gelişimi: Acemilikten Olgunlaşmaya Giden Zorlu Yol. R. Özyürek, F. Korkut Owen ve D. Owen (Editörler), Gelişen Psikolojik Danışma ve Rehberlik, Meslekleşme Sürecinde İlerlemeler. Ankara: Nobel Yayınları.

Yeşilyaprak, B. (2009). Türkiye'de psikolojik danışma ve rehberlik alanının geleceği: Yeni açlımlar ve öngörüler. Ankara Üniversitesi Eğitim Bilimleri Fakültesi Dergisi, 42(1), 193- 213.

Yıldırım, A. ve Şimşek, H. (2013). Sosyal Bilimlerde Nitel Araştırma Yöntemleri. Ankara: Seçkin Yayınları. 